\title{
Ano dois: Questionar e celebrar
}

\author{
Maria Helena Serôdio
}

Na transposição do "limite" que representou a entrada no ano dois da publicação desta revista, gostariamos de nos rever nas palavras de Strehler acima transcritas, adoptandoas como divisa do nosso trabalho aqui.

Porque são, fundamentalmente, três as razões que nos movem nesta interpelação do que no teatro e pelo teatro se faz: dar testemunho do que vemos, lemos e investigamos; entender (ou procurar entender) tudo isso em função de conceitos e metodologias que incansavelmente interrogamos e depuramos; e, finalmente, celebrar festivamente o que julgamos merecer o nosso (ainda que discutivel) aplauso. Por um gesto de amor ao teatro e à vida.

Não nos movem imprudentes gestos de impugnação de um qualquer objecto cénico, nem nos parece razoável focalizar interstícios de escaramuças, por mais que essas receitas pareçam atrair entusiasmos fátuos e néscias maledicências. 0 que não significa que nos furtemos a um esclarecido debate de ideias e a uma exigente confrontação de opções estéticas. Mas gostariamos que na vida - como no teatro de que falamos - pudéssemos superar estereótipos gastos e reclamar a emancipação das ideias, dos gostos e dos afectos.

De tão desmedido que é, este programa faz-nos esquecer as condições inacreditáveis em que o praticamos: uma devoção totalmente "generosa" (alguém "de fora" saberá disto?), um infatigável labor de escrita e revisão (não há olhos e braços outros que nos assistam...), uma obsessiva marcação de prazos acelerados e quase autofágicos (em estridente conflito com tudo o que fazemos para além deste compromisso de "missão").

E assim, nesta singular obstinação, ai está mais um número da Sinais de cena a dar conta do que queremos que não seja esquecido. A começar pelo Prémio da Crítica (e as três Menções Especiais) que o júri da Associação Portuguesa de Críticos de Teatro atribuiu, no seu rosto plural e nas suas diversas fundamentações: Para além do Tejo (do Teatro Meridional e projecto Percursos, do Centro Cultural de Belém), 0 fazedor de teatro (da Companhia de Teatro de Almada), Luz/Interior (um projecto de Rita Só, co-produzido pela Casa Conveniente e João Garcia Miguel um modesto mas profundo gesto de amor pela vida que, através do teatro, arde sobre as cenas do mundo inteiro.'

Unipessoal) e A cabra, ou quem é Silvia? (do Teatro da Comuna). Os quatro objectos cénicos distinguidos representam modos diversos de entender - e exercer - o gesto criativo e nas alegações públicas, que apresentámos no Salão Nobre do Teatro Nacional D. Maria II (por amável cedência do seu Director, António Lagarto), pudemos dizer das razões que justificaram a selecção feita. E, curiosamente, constatámos que o desacordo dos artistas relativamente ao discurso analítico não deplora apenas as palavras aceradas de crítica: pode também, como o fez a fundadora e principal criadora da Casa Conveniente, verberar o elogio, quando ele não alinha com expectativas outras. Mas podendo isto ser sintoma de alguma insuficiência de debate artístico entre nós, não nos pode demover de prosseguir, pela nossa parte de críticos, uma atenta e problematizadora abordagem do que se faz (ou fez) em teatro, sem nos rendermos à mui portuguesa tentação da renúncia complacente.

Outras celebrações - centenárias as quatro - ocupam este número: a morte de Rafael Bordalo Pinheiro, infatigável caricaturista e enamorado do teatro; a formação entre nós de companhias que visavam cumprir o programa que Antoine propunha do naturalismo em teatro: o Teatro Livre (1904) e o Teatro Moderno (1905); o do lugar da invenção, no início do século XX, do teatro irlandês: o Teatro da Abadia; e o de Tchekov (pela data do seu falecimento, a 1904). Nestes quatro casos, a celebração implicou renovadas investigações que trouxessem algumas das circunstâncias, nomes e lugares por onde passaram os protagonistas da mudança. Para o Arquivo solto, Maria Virgílio Cambraia Lopes recorda o inventor do Zé Povinho e os seus olhos postos em cena, enunciando as suas visões do teatro: por autores, artistas, empresários, teatros e até ... por si próprio, "encravado" numa cadeira de rodas, com um pé partido, e sem poder ir ao teatro. No artigo de Luiz Francisco Rebello, para além da substantiva informação (também avaliativa), esclarece-se um facto que durante algum tempo permaneceu equívoco: afinal, a presença de Antoine nos palcos portugueses ocorreu apenas uma vez, em 1903. No de Paulo Eduardo Carvalho, para além da "notícia de fora" que
'Giorgio Strehler, Un théâtre pour la vie (1974), trad. Emmanuelle Genevois, Paris, Fayard, 1980, p. 3, tradução minha. 
dá conta das múltiplas actividades concitadas em Dublin no final de 2004, em torno do centenário, refere o autor - ainda que com brevidade - a fortuna dos dramaturgos irlandeses em Portugal. Por seu lado, Rui Pina Coelho apresenta uma longa e exaustiva lista de espectáculos (com algumas das suas respectivas ilustrações) que os textos de Tchekov (ou inspirados pela figura e obra do autor russo) fizeram passar pelos palcos portugueses.

Uma outra lista, organizada pacientemente por Sebastiana Fadda, sinaliza os livros de e sobre teatro que foram publicados em Portugal em 2004, encerrando dessa maneira uma rubrica - Leituras - que prevê a inquirição a peças originais, reedições e edições críticas, bem como traduções e estudos (ou documentos) sobre teatro. Dá, assim, conta de alguma da actividade editorial neste campo que, entre nós, ainda é errática, insuficiente e pouco publicitada. Para ela contámos com a participação de estudiosos do teatro, mas também de especialistas em tradução (bem vindos a este nosso esforço conjunto!), bem como de investigadores que apuram os seus conhecimentos sobre o teatro em Portugal, residindo em Portugal, ou de longe, como é o caso de Graça dos Santos. E quase sempre propusemos o "confronto" entre o que é dito sobre os livros e algumas das suas consequências teatrais, com fotografias de cena que relembrem os autores ou as circunstâncias das realizações cénicas de que se fala.

E é ainda de escrita que nos fala a rubrica Em rede, nela revelando Rui Cintra como na internet se podem procurar, ler e imprimir textos de dramaturgos clássicos, usando das virtualidades ao alcance de um "clique".

Nessa equação entre escrita e cena surge também a notícia de autores catalães vistos em Paris, numa visitação rápida às potencialidades de uma dramaturgia rica e em ascensão, de acordo com a opinião competente de Francesc Massip. E de Paris chega-nos, pela escrita de Jean-Pierre Wurtz, uma informada descrição de como se organiza o tecido teatral em França, com particular destaque para as responsabilidades cometidas aos seus poderes públicos nacionais e regionais - na animação da vida artística feita em palco.

Em cena, mas em terras portuguesas, lembramos alguns espectáculos deste início de 2005, diversos nas geografias que percorreram - em Évora, Coimbra, Porto e Lisboa -, no fôlego institucional em que se recortaram, e nas opções estéticas que mobilizaram. Nessa declarada multiplicação de propostas, assinale-se a atenção a uma dramaturgia contemporânea de ácido comentário à vida que nos cerca (nos repertórios do Cendrev e dos Artistas Unidos, encenados, respectivamente, por Luis Varela, Jorge Silva Melo e Andreia Bento), ou tecendo enredos enigmáticos (que Cristina Carvalhal tomou de Gombrowicz). Há ainda uma visitação a Mahabharata na arte da manipulação de marionetas, bem como as mais esplendorosas e memoráveis criações que os dois Teatros Nacionais ergueram neste início do ano: em Lisboa, a partir de Gil Vicente (Maria Emilia Correia a inventar um universo mágico e festivo para a co-produção que dirigiu) e no Porto, a partir dos Ubus, de Jarry, em imaginativa tradução de Luisa Costa Gomes, uma produção brilhante dirigida por Ricardo Pais, com excelentes e competentíssimas colaborações criativas, que fazem explodir em cena um virtuosismo de ironia e alacridade, em rigorosos e lúdicos registos de interpretação.

Um outro espectáculo que os "Passos em volta" relembram é o de Luis Castro que tematiza questões de identidade na performatividade de um corpo que se expõe em coreografias diversas na forma de expressão e intenção de comunicabilidade. E essa acaba por ser a questão maior de que falam também, de outro modo, Miguel Abreu e André Murraças aos entrevistadores Miguel-Pedro Quadrio e Mónica Guerreiro, debatendo as suas propostas muito pessoais de teatro de "género". Compondo razões pertinentes para fundamentar o teatro que insistem em criar, estes criadores desvendam a interpelação que lançam aos hábitos e juizos sociais que integram o conceito de género, como emergindo numa lógica de padronização que muitas vezes rasura formas outras de entender a sua relação com 0 sexo, a sexualidade e a arte em geral.

Mas no conceito amplo das artes performativas, que a revista interpela e celebra, cabe ainda a magia das artes do novo circo de que nos fala Isabel Alves Costa, de forma conhecedora, e que - por coincidência de tempos e de afectos - surge de outro modo no portefólio de Susana Paiva a propósito da sua participação no projecto Percursos, em iniciativa do CCB. No conjunto de imagens, que aqui a fotógrafa nos dá a ver, não estará resumido ou sinalizado o seu - já longo e rico - trajecto, atento a tantas e variadas realidades de que vem dando testemunho. Mas está uma forma de "confissão": a do deslumbramento que Ihe trouxe esta renovada forma de efabulação que Ihe "devolve a magia e o mistério que, por vezes, faltam ao quotidiano".

A abertura às artes performativas que aqui se pratica é, de facto, a celebração da vida nestas dimensões tão manifestamente plurais. 